\title{
PENYELESAIAN PERKARA PENCURIAN SEBAGAI TINDAK PIDANA RINGAN PASCA PERATURAN MAHKAMAH AGUNG NOMOR 2 TAHUN 2012
}

\author{
Gede Mahadi Waisnawa Hanata Putra, I N. Putu Budiartha, Ni M. Sukaryati Karma \\ Fakultas Ilmu Hukum Universitas Warmadewa, Denpasar - Bali, Indonesia \\ doewaisnawa@gmail.com, budiarthaputu59@gmail.com, sukariati64@gmail.com
}

\begin{abstract}
Abstrak
Hukum Pidana Indonesia saat ini merupakan warisan dari Pemerintah Hindia Belanda yang telah diadaptasi dan disahkan Undang-Undang No. 16 tahun 1946 untuk diterapkan secara nasional. Tujuan penelitian ini adalah untuk mendeskripsikan pengaturan pencurian terhadap Tindak Pidana Ringan dalam KUHP sebelum Peraturan Mahkamah Agung Nomor 2 Tahun 2012 dan menggambarkan konsekuensi yuridis Peraturan Mahkamah Agung Nomor 2 Tahun 2012 terhadap pencurian sebagai Tindak Pidana Ringan dalam KUHP. Penelitian ini menggunakan metode penelitian hukum normatif. Hasil penelitian menunjukan bahwa menurut Pasal 206 KUHAP, tata cara pemberian kewenangan penyidikan dan peninjauan kembali perkara dilakukan oleh penyidik sendiri dan tidak boleh diganggu oleh jaksa. Perpres ini menyesuaikan pasal 364, 373, 379, 384, 407 dan pasal 482 KUHP menjadi Rp. 2.500.000,00. Oleh karena itu, penuhi elemen persyaratan ini dan masukkan kasus nilai komoditas tidak melebihi Rp. 2.500.000,00. Oleh karena itu, perkara tersebut diperiksa dengan prosedur yang dipercepat, yang diadili oleh hakim, dan penugasan serta peninjauan kembali perkaranya dilakukan oleh penyidik sendiri tanpa campur tangan jaksa.
\end{abstract}

Kata kunci: Pencurian, Peraturan Mahkamah Agung Nomor 2 Tahun 2012, Tindak Pidana Ringan

\begin{abstract}
Indonesian Criminal Law is currently a legacy from the Dutch East Indies Government which has been adapted and passed by Law No. 16 of 1946 to be implemented nationally. The purpose of this research is to describe the regulation of theft of minor crimes in the Criminal Code before the Supreme Court Regulation Number 2 of 2012 and to describe the juridical consequences of Supreme Court Regulation No.2 of 2012 on theft as a minor criminal act in the Criminal Code. This research uses normative legal research methods. The results show that according to Article 206 of the Criminal Procedure Code, procedures for granting authority to investigate and review cases are carried out by the investigator himself and should not be disturbed by the prosecutor. This Perpres adjusts articles 364, 373, 379, 384, 407 and article 482 of the Criminal Code to Rp. 2,500,000.00. Therefore, fulfill this element of the requirement and enter a case where the value of the commodity does not exceed Rp. 2,500,000.00. Therefore, the case is examined by expedited procedure, which is tried by a judge, and the assignment and review of the case is carried out by the investigator himself without the interference of the prosecutor.
\end{abstract}

Keywords: Theft, Supreme Court Regulation Number 2 of 2012, Minor Crime

\section{PENDAHULUAN}

Indonesia adalah negara hukum. Pasal 1 ayat (3) UUD 1945 mengatur hal ini yang menyatakan bahwa "Indonesia adalah negara hukum". Warga negara yang menikmati status yang sama di depan hukum, siapa pun yang melanggar hukum akan dihukum sesuai dengan hukum yang berlaku (Muntoha, 2009). Dalam penegakan hukum penggunaannya didasarkan pada hukum pidana substantif dan hukum pidana formil atau hukum acara pidana. Negara kesatuan Republik Indonesia merupakan salah satu negara utama yang mengajukan ketentuan hukum yang berlaku. Aturan hukum aktif yang berlaku di Indonesia jelas merupakan bagian penting dari membangun keamanan, perdamaian dan kehidupan damai. Salah satu bidang hukum untuk menjaga ketertiban dan keamanan warga negara Indonesia adalah hukum pidana.

Hukum pidana Indonesia adalah salah satu norma terpenting untuk mencapai keadilan. KUHP adalah dasar yang kuat untuk menentukan tindakan ilegal dan memberikan sanksi tegas kepada pelanggar (Ariyanti, 2019; Zaidan, 2014). KUHP adalah ketentuan positif utama untuk tindak pidana, dan pelaksanaannya disetujui oleh Undang- Undang Nomor 10 pada tanggal 1 Januari 1946 Peraturan Hukum Pidana Indonesia. Selain banyak ketentuan yang memasukkan hukum pidana, hukum pidana 
saat ini menjadi hukum pidana utama yang berlaku (Kartanegara, 2002; Zulkifli, Fitriati, \& Ferdi, 2018). Hukum pidana yang saat ini berlaku di Indonesia merupakan warisan dari Pemerintah Hindia Belanda. Undang-undang tersebut telah diubah dengan UU No. 30 dan kemudian diberlakukan secara nasional 16 Januari 1946. Indonesia masih menggunakan "hukum pidana" pemerintah Hindia Belanda karena pemerintah tidak dapat membuat undang-undang pidana sendiri sejak berlakunya Proklamasi Kemerdekaan.

Pada era sekarang ini, permasalahan hukum pidana telah mendapatkan pembahasan dan perhatian yang luas baik secara teori maupun praktek, bahkan dicoba untuk menyusun KUHP (Rompas, 2013). Upaya ini bertujuan untuk mengatasi berbagai kelemahan dan kekurangan dari UU Pidana yang ada saat ini yang merupakan warisan dari zaman penjajahan, bahkan masih digunakan pada masa reformasi merdeka. Fakta membuktikan bahwa banyak ketentuan yang tidak lagi sejalan dengan Pancasila. Semangat dan semangat serta semangat UUD 1945, serta keadaan dan kondisi masyarakat saat ini (Niniek, 2007).

Hal ini selanjutnya mengatur tindak pidana pencurian yang nilai kerugiannya kurang dari Rp. 2.500.000 tidak bisa ditahan. Dasar dari diundangkannya Perma No. 2/2012 ini adalah untuk mengupayakan rasa keadilan kepada masyarakat, khususnya dalam penyelesaian perkara pelanggaran ringan. Secara teknis, hukum yang disebut "tipling" adalah kejahatan, dihukum hingga 3 bulan penjara atau penjara dan / atau denda dan pelanggaran hingga 7.500. Oleh karena itu, esensi dari Peraturan Mahkamah Agung ini adalah pada kenyataannya tanggal 2 Februari 2012 tidak berdasarkan harga rupiah, tetapi dalam tindak pidana, ancaman hukum maksimal 3 bulan tanpa penahanan. Mahkamah Agung 2012 Pasal 2 Pasal 1 menjelaskan bahwa istilah 250 rupiah dalam Pasal 364, 373, 379, 384, 407 dan 482 KUHP ditafsirkan sebagai 2,5 juta.

Menurut "Pemeriksaan, Banding, Pencabutan, dan Sidang Ulang" Harahap (2009) bahwa pencurian adalah tindak pidana dan dapat digolongkan sebagai prosedur penyidikan tindak pidana ringan. Ada tiga kejahatan dasar pencurian: yang pertama adalah kejahatan pencurian, dan bobotnya harus sesuai dengan ketentuan Pasal 363; kedua, kejahatan umum pencurian harus tunduk pada Pasal 362, dan yang kedua adalah kejahatan pencurian kecil. Jika nilai barang curian tidak melebihi 250, ketentuan Pasal 364 harus dipatuhi. Rupiah Indonesia (Hamzah, 2004).

Diharapkan dengan diundangkannya peraturan Mahkamah Agung tersebut menjadi langkah awal bagi pemerintah dan DPP untuk melakukan amandemen Undang-Undang Pidana dan Hukum Acara Pidana yang dinilai semakin maju seiring dengan perkembangan zaman di era ini. Sebelum berlakunya Peraturan Mahkamah Agung, banyak kejahatan yang dihukum berat meskipun hanya menjadi sasaran sekunder. Pada saat yang sama, pencurian serius tidak jarang terjadi, tetapi dapat membebaskan pelakunya.

Sebagai contoh, pada Pengadilan Negeri Stabat Sumatera Utara atas kasus pencurian terdakwa Ismail Sitepu (30), Lian Sempurna (28) dan Awang Setiawan. Keputusan jaksa dan hakim berbeda. Mereka didakwa melakukan pencurian sejumlah biji sawit, salah satunya Ngawang senilai 410.000 rupiah dan satu lagi senilai 500.000 rupiah. Kasus tersebut bermula ketika keduanya diam- diam masuk ke perkebunan sawit dan mencuri 34 tandan buah sawit pada 7 Maret 2015. Setelah itu, mereka membawa tandan sawit tersebut ke halaman dan menutupinya dengan daun. Tiga hari kemudian, mereka datang ke lokasi dan mengirimkan tandan kelapa sawit secara berkelompok. Tahap kedua, keduanya ditangkap oleh satpam di perkebunan kelapa sawit. Ismail dan Lien juga dibawa ke kantor polisi dan diadili karena menghukum pemilik kelapa sawit, kehilangan 500.000 rupiah. Pada saat inilah pengadilan berpisah. JPU membenarkan bahwa mereka akan diadili secara terpisah berdasarkan Pasal 363 ayat (1) KUHP Keempat, dengan hukuman maksimal 9 tahun penjara. Namun, Pengadilan Distrik (PN) Stabat menyatakan sebaliknya. Menurut Pasal 2 Peraturan Mahkamah Agung (Tetap) tahun 2012 tentang penyesuaian ketentuan pembatasan dan denda untuk tindak pidana ringan dalam KUHP, perkara ini telah dimasukkan ke dalam Pasal 364 KUHP. Berdasarkan pertimbangan tersebut, hakim tunggal Sunoto kemudian memvonisnya sesuai dengan Pasal 364 KUHP dan Keputusan Tetap Nomor 2 Tahun 2012.

Berdasarkan uraian permasalahan yang telah penulis kemukakan di atas, penelitian ini dilakukan dengan tujuan mendeskripsikan pengaturan pencurian terhadap Tindak Pidana Ringan dalam KUHP sebelum Peraturan Mahkamah Agung Nomor 2 Tahun 2012 dan menggambarkan konsekuensi yuridis Peraturan Mahkamah Agung Nomor 2 Tahun 2012 terhadap pencurian sebagai Tindak Pidana Ringan dalam KUHP. 


\section{METODE}

Penelitian ini didesain dengan menggunakan metode penelitian hukum normatif, yaitu mengkaji lebih jauh tentang isi peraturan perundang-undangan. Metode permasalahan yang digunakan adalah metode hukum dan metode konseptual. Sumber bahan hukum terdiri dari dua jenis yaitu bahan hukum primer dan bahan hukum sekunder. Data yang sudah terkumpul dianalisis menggunakan metode deskriptif dan disajikan dengan metode informal.

\section{HASIL DAN PEMBAHASAN}

\section{Peraturan tentang Tindak Pidana Pencurian sebelum Putusan Mahkamah Agung} Nomor 2 Tahun 2012 dalam KUHP

Hukum secara tepat mengatur masyarakat dan mendapatkan keuntungan darinya dengan menempatkan konten yang diwajibkan atau diizinkan, dan sebaliknya. Hukum dapat menentukan kualifikasi suatu perilaku tertentu berdasarkan hukum, atau dapat dikatakan sebagai kualifikasi yang melanggar hukum. Tindakan yang diambil sesuai dengan hukum tidak menjadi masalah, juga tidak perlu dipertanyakan, masalahnya terletak pada perilaku ilegal. Padahal, yang dipertimbangkan dan dipertimbangkan oleh undang-undang justru adalah jenis perilaku yang terakhir, yang melanggar baik perilaku hukum aktual maupun perilaku hukum yang mungkin terjadi.

Dalam KUHP tindak pidana pencurian diatur dalam beberapa pasal termasuk Pasal 362 KUHP. Diketahui bahwa klausul di atas merujuk pada kejahatan pencurian sebagai kejahatan yang ditetapkan secara formal, yang seharusnya dilarang dan dapat dihukum, dalam hal ini adalah tindakan "pengambilan". Istilah "memperoleh" dalam arti sempit terbatas pada menggerakkan tangan dan jari, memegang benda dan memindahkannya ke lokasi lain (Projodikoro, 2003).

Oleh karena itu, kita semua tahu bagaimana hukum pidana mengontrol pencurian semacam ini, tetapi berdasarkan penjelasan tersebut, dalam hal ini kita tidak dapat melihat makna pencurian secara cermat dan jelas. Tidak ada yang bisa memastikan bagaimana pencurian itu terjadi, tapi itu bisa ditentukan dari pencuriannya. Jadi kita bisa menjelaskan pencurian itu sebagai pencurian suatu benda atau harta benda milik orang lain dengan cara melanggar hukum yang dapat merugikan orang yang memiliki barang/benda tersebut. Disimpulkan bahwa dalam hal ini yang dimaksud pencurian adalah perbuatan seseorang yang melanggar hukum untuk mendapatkan harta atau barang milik orang lain.Berdasarkan uraian di atas, maka jelaslah kita mengetahui adanya pencurian tersebut di atas.

\section{Penyelesaian Perkara Pencurian sebagai Tindak Pidana Ringan sebelum dan sesudah Perma}

Acara pidana melibatkan banyak pihak, yaitu tersangka atau tersangka, penyidik, penyidik, jaksa dan penasehat hukum, serta hakim yang netral atau tidak berpihak pada masing-masing pihak. Kemudian, peserta ini ditambahkan ke sistem tatap muka yang disebut "Sistem Pemeriksaan Reporter". Sistem interogasi yang digunakan di masa lalu menggunakan terdakwa sebagai subjek pengujian, sedangkan hakim dan jaksa berada di pihak yang sama. Namun dalam beberapa kasus, dalam proses penyelesaian perkara, seperti kejahatan ringan, tidak semua pihak tersebut bertatap muka. Dalam UU Hukum Acara Pidana pasal 16 terdapat tiga bentuk peninjauan kembali acara pengadilan, yang mengatur penggunaan prosedur peninjauan kembali secara rutin, singkat atau ad hoc dan cepat untuk memeriksa perkara di sidang pengadilan. Dasar pembedaan dapat dilihat dari jenis tindak pidana atau kemudahan pembuktiannya.

Untuk kejahatan ringan, pemeriksaan cepat akan dilakukan. Bentuk pemeriksaan kejadian cepat di HIR disebut crash box. Seperti pemeriksaan peristiwa singkat, pemeriksaan peristiwa cepat juga dipandu oleh pemeriksaan peristiwa reguler (dengan beberapa pengecualian).

Inspeksi insiden cepat pada dasarnya mengacu pada inspeksi insiden rutin. Sebelum membahas tata cara peninjauan melalui prosedur eksplisit, terlebih dahulu kami akan meredefinisi arti dari pelanggaran ringan. Standar yang digunakan untuk menetapkan prosedur yang ringan biasanya dilihat sebagai ancaman proses pidana yang diancam dengan pidana penjara paling lama 3 bulan dan/atau denda paling banyak Rp. 7,500.00, tetapi tidak mempengaruhi pelanggaran sedikit penghinaan seperti yang didefinisikan dalam seni 315 KUHP.

Mirip dengan tinjauan singkat, pengadilan lokal menetapkan tanggal tertentu dalam proses peninjauan yang dipercepat, khususnya untuk meninjau kasus-kasus kejahatan ringan. Berdasarkan Pasal 206 KUHAP, pengadilan memutuskan untuk mengadili perkara dengan acara penyidikan pidana 
ringan pada hari tertentu dalam waktu 7 hari. Prosedur otorisasi dan peninjauan kasus dilakukan oleh penyidik sendiri, tanpa campur tangan dari jaksa. Peraturan ini sedikit berbeda dengan prosedur inspeksi untuk kursus reguler atau jangka pendek. Ketentuan khusus ini mencabut ketentuan umum yang mengatur kewenangan jaksa dalam menjalankan persidangan. Oleh karena itu, penyidik mengambil alih kantor kejaksaan milik kejaksaan dalam proses peninjauan kembali melalui prosedur yang dipercepat. Menurut Pasal 205 (2) UU Acara Pidana, penyidik yang "menjalankan kekuasaannya" oleh jaksa penuntut langsung menyerahkan berkas perkara ke pengadilan dan berhak untuk langsung menyerahkan terdakwa beserta barang bukti, saksi, ahli atau juru bahasa ke pengadilan.

Penyidik memiliki hak untuk mengajukan terdakwa, bukti, saksi, ahli atau penerjemah ke pengadilan dalam waktu tiga hari sesuai dengan Pasal 205 ayat 2 UU Acara Pidana. Definisi "tiga hari" agak ambigu karena undang-undang tidak menetapkan tiga hari sebagai periode terpanjang atau terpendek. Menurut Harahap (2009), "dalam tiga hari" adalah jumlah minimal yang ditentukan dalam Pasal 146 (2) dan Pasal 152 (2) KUHAP, yang harus dalam jangka waktu berikutnya. Masa persidangan untuk menerima surat panggilan dari terdakwa dan saksi dimulai setidaknya tiga hari. Oleh karena itu, syarat "dalam tiga hari" adalah standar minimal, dalam sidang puasa ini penyidik tidak diperkenankan menunjukkan terdakwa dan saksi dalam waktu tiga hari. Lebih dari tiga hari diperbolehkan, tetapi kurang dari tiga hari harus dianggap tidak valid. Pada hari persidangan kasus pidana ringan akan disidangkan pada hari yang sama. Ketentuan ini tunduk pada Pasal 207 ayat (1) huruf b UU Acara Pidana.

Ketika kasus selesai dan persyaratan formal untuk kehadiran terdakwa dan saksi terpenuhi, hakim tidak punya cara lain untuk menghindari sidang kasus hari itu. Saat itu, hakim sedang tidak bertugas menyidangkan kasus tersebut. Para hakim memang dapat menunda peninjauan formal atas kasus tersebut dalam proses pengadilan, tetapi hal ini bertentangan dengan tujuan peninjauan jalur cepat tersebut. Apabila terdakwa tidak hadir tanpa alasan, menurut Pasal 214 ayat (2) KUHAP, hakim tetap dapat memberikan putusan terhadap verstek. Pada saat yang sama, tidak mungkin melihat ketidakhadiran saksi. Hal ini juga terkait dengan saksi bukan tersumpah yang diatur dalam Pasal 208 UU Acara Pidana.

Menurut Pasal 207 ayat (2) KUHAP, setelah pengadilan menerima perkara tersebut, hakim yang bertugas memeriksa perkara tersebut memerintahkan panitera untuk mencatatnya dalam register. Pasal 205 (3) UU Acara Pidana menetapkan bahwa hakim yang bertugas memeriksa perkara adalah satu-satunya hakim. Oleh karena itu, penyidik tetap bertanggung jawab atas kasus yang tidak terdaftar. Jika kasusnya tidak lengkap atau tidak memenuhi persyaratan formal, metode ini dapat digunakan. Jika sudah terdaftar, hakim bisa langsung menyidangkan perkara di hari yang sama. Dalam prosedur pemeriksaan kecepatan, kasus ini dituntut tanpa tuntutan. Surat dakwaan dianggap telah masuk dalam catatan pendaftaran karena dalam catatan pendaftaran meliputi nama, tanggal dan tanggal lahir, umur, jenis kelamin, kewarganegaraan, domisili, agama, pekerjaan, dan tindak pidana yang didakwakan.

Keputusan yang ditinjau melalui prosedur eksplisit juga berbeda dari prosedur biasa. Keputusan dalam prosedur pemeriksaan cepat ini tidak dibuat secara eksklusif dan individual. Putusan hanya dicatat dalam daftar catatan perkara oleh hakim, dan kemudian dicatat dalam buku rekening oleh asisten toko. Putusan yang termasuk dalam putusan hanya berupa tanda tangan dan ditandatangani oleh hakim dan panitera. Oleh karena itu, penyidik yang menangani perkara tersebut telah melampirkan daftar catatan putusan pada berkas perkara tersebut. Kemudian, panitera mencatatnya dalam daftar perkara yang disebutkan dalam Pasal 207 ayat (2) KUHAP. Menurut tafsir Pasal 209 KUHAP, langkah ini dirancang untuk mempercepat penyelesaian perkara, namun tetap bisa dijalankan secara lengkap dan akurat. Menurut Pasal 205 (3) UU Acara Pidana, pengadilan diperiksa oleh hakim tingkat pertama dan tingkat terakhir.

Oleh karena itu, terdakwa yang menentang putusan tidak dapat mengajukan banding. Tergugat yang menentang putusan dapat mengajukan banding ke Mahkamah Agung sesuai dengan KUHAP 244. Namun, Pasal 205 (3) UU Acara Pidana tidak berhenti sampai di situ. Pasal tersebut juga menetapkan bahwa jika putusan yang dikeluarkan adalah putusan perampasan kemerdekaan, Terdakwa masih bisa naik banding. Atas kejadian ini, tergugat bisa naik banding. Selain kasus pidana ringan, pemeriksaan cepat juga digunakan untuk menyelesaikan pelanggaran lalu lintas jalan raya. 
Pasal 2 ayat (2) Perma No. 2/2012 mengatur bahwa jika nilai barang atau uang tidak melebihi 2,5 juta rupiah (2,5 juta rupiah), ketua pengadilan segera menunjuk hakim untuk memeriksa dan mengadili. Pengadilan dan putusan. Kasus ini harus segera ditinjau ulang sesuai dengan Pasal 205-210 UU Acara Pidana. Menurut pernyataan ini, jelas bahwa menangani kasus pencurian kecil berarti melakukan persidangan selama proses peninjauan yang dipercepat. Pada bagian ini penulis akan menjelaskan bagaimana tata cara penyelesaian perkara tidak melebihi Rp.2.500.000,00 sesuai dengan Pasal 2 Undang-Undang Hukum Acara Pidana (KUHAP).

Bagian pertama yang disebutkan dalam Bab 16 adalah tata cara memanggil terdakwa, saksi atau ahli. Bagian kedua mengatur sengketa yudisial, dan bagian ketiga mengatur prosedur peninjauan kembali. Oleh karena itu, pemeriksaan peristiwa cepat pada dasarnya mengacu pada pemeriksaan peristiwa biasa. Sebelum diskusi singkat tentang proses peninjauan, definisi tindak pidana ringan akan didefinisikan. Secara umum terlihat dari ancaman dugaan tindak pidana, kurungan atau kurungan sampai dengan 3 bulan atau kurungan, dan / atau denda sampai dengan Rp, bahwa tindakan ini telah menjadi patokan dalam penetapan persidangan ringan prosedural. $7.500,00$, tetapi tidak mempengaruhi tindak pidana penghinaan ringan yang diatur dalam Pasal 315 KUHP.

Mirip dengan tinjauan prosedur jangka pendek, pengadilan distrik menetapkan tanggal tertentu dalam tinjauan prosedur dipercepat, yang secara khusus digunakan untuk meninjau kasus-kasus kejahatan ringan. Menurut Pasal 206, pengadilan menentukan hari tertentu dalam waktu 7 hari untuk mengadili kasus yang melibatkan prosedur peninjauan kejahatan ringan.

Pada hari perkara pidana kecil diterima di pengadilan, sidang akan digelar pada hari yang sama. Ketentuan ini diatur dalam Pasal 207 ayat (1) huruf b UU Acara Pidana. Ketika kasus selesai dan persyaratan formal untuk kehadiran terdakwa dan saksi terpenuhi, hakim tidak punya cara lain untuk menghindari sidang kasus hari itu. Hakim berkewajiban untuk tidak mendengarkan kasus tersebut. Para hakim memang dapat menunda peninjauan formal atas kasus tersebut dalam proses pengadilan, tetapi hal ini bertentangan dengan tujuan peninjauan jalur cepat tersebut. Apabila terdakwa tidak hadir karena alasan yang tidak dapat dibenarkan, hakim tetap dapat memberikan putusan sesuai dengan Pasal 214 ayat (2) UU Acara Pidana. Sementara karena tidak ada keterangan saksi, persidangan tidak bisa ditunda karena keterangan saksi bisa dibacakan. Hal ini juga terkait dengan saksi bukan tersumpah yang diatur dalam Pasal 208 UU Acara Pidana.

Menurut Pasal 207 ayat (2) KUHAP, setelah pengadilan menerima perkara tersebut, Hakim yang bertanggung jawab atas kasus tersebut memerintahkan panitera untuk mencatatnya. Pasal 205 (3) UU Acara Pidana menetapkan bahwa hakim yang bertugas memeriksa perkara adalah satu-satunya hakim. Oleh karena itu, penyidik tetap bertanggung jawab atas kasus yang tidak terdaftar. Jika kasusnya tidak lengkap atau tidak memenuhi persyaratan formal, metode ini dapat digunakan. Artinya jika perkara tidak lengkap atau tidak memenuhi persyaratan formal, maka tidak boleh didaftarkan terlebih dahulu agar dapat dikembalikan kepada penyidik. Jika sudah terdaftar, hakim bisa langsung menyidangkan perkara di hari yang sama. Dalam prosedur pemeriksaan kecepatan, kasus ini dituntut tanpa tuntutan. Surat dakwaan dianggap telah masuk dalam catatan pendaftaran karena dalam catatan pendaftaran meliputi nama, tanggal dan tanggal lahir, umur, jenis kelamin, kewarganegaraan, domisili, agama, pekerjaan, dan tindak pidana yang dituduhkan.

Keputusan yang ditinjau melalui prosedur eksplisit juga berbeda dari prosedur biasa. Keputusan dalam pemeriksaan cepat ini tidak eksklusif dan individual. Putusan hanya dicatat dalam daftar catatan perkara oleh hakim, dan kemudian dicatat dalam buku rekening oleh asisten toko. Putusan hanya muncul dalam bentuk tanda tangan termasuk putusan, dan ditandatangani oleh hakim dan panitera. Oleh karena itu, penyidik yang menangani perkara ini telah melampirkan daftar catatan putusan pada berkas perkara. Kemudian, panitera mencatatnya dalam daftar perkara yang disebutkan dalam Pasal 207 ayat (2) KUHAP.

Menurut tafsir Pasal 209 KUHAP, langkah ini dirancang untuk mempercepat penyelesaian perkara, namun tetap bisa dijalankan secara lengkap dan akurat. Menurut Pasal 205 (3) KUHAP, pengadilan diperiksa oleh hakim tingkat pertama dan terakhir. Artinya keputusan sudah final. Oleh karena itu, terdakwa yang menentang putusan tidak dapat mengajukan banding. Terdakwa yang menentang putusan dapat, sesuai dengan ketentuan Pasal 244 KUHAP, mengajukan gugatan untuk membatalkan putusan semula di Mahkamah Agung. Namun, ketentuan Pasal 205 (3) KUHAP tidak terbatas pada hal tersebut. Pasal tersebut juga menetapkan bahwa jika putusan yang dikeluarkan 
adalah putusan perampasan kemerdekaan, tergugat masih dapat mengajukan banding. Dalam kejadian ini, tergugat dapat mengajukan banding.

Dalam hal ini, sesuai dengan ketentuan Pasal 2 ayat 2 sesuai dengan ketentuan Pasal 205-210 KUHAP, melalui rapid review procedure pokok perkara dapat diselesaikan dengan cepat tanpa melebihi Rp 2.500.000,00. PERMA 2012 No. 02. Artinya, peninjauan prosedural yang dipercepat pada dasarnya mengacu pada peninjauan kembali yang dilakukan melalui prosedur konvensional.Dalam hal penetapan ancaman dugaan tindak pidana, prosedur biasanya menjadi tolok ukur untuk menentukan perkara peninjauan prosedural ringan, dan dapat dihukum maksimal 3 bulan. Hukuman penjara. Atau kurungan, atau denda paling banyak Rp. 7.500,00, tetapi tidak mempengaruhi tindak pidana penghinaan ringan yang diatur dalam Pasal 315 KUHP.

Mengenai putusan perkara pidana ringan yang dilakukan melalui peninjauan prosedur yang dipercepat, tidak ada putusan tersendiri yang dikeluarkan, melainkan dicatat dalam daftar catatan perkara, yang kemudian dicatat oleh panitera dalam buku dan ditandatangani oleh hakim dan panitera. Keputusan itu disahkan pada hari kasus itu disidangkan, dan penundaan dapat ditoleransi jika terdakwa memintanya. Vonis bisa dijatuhkan hanya dengan memvonis hakim yang memiliki bukti sah untuk mendukungnya.

\section{SIMPULAN DAN SARAN \\ 1. Simpulan}

Berdasarkan hasil dan pembahasan di atas, ada beberapa simpulan yang dapat dibuat, yaitu: pertama, dalam KUHP tindak pidana pencurian diatur dalam beberapa pasal termasuk Pasal 362 KUHP. Kedua, menurut Pasal 206 KUHAP, tata cara pemberian kewenangan penyidikan dan peninjauan kembali perkara dilakukan oleh penyidik sendiri dan tidak boleh diganggu oleh jaksa. Perpres ini menyesuaikan pasal 364, 373, 379, 384, 407 dan pasal 482 KUHP menjadi Rp. 2.500.000,00. Oleh karena itu, penuhi elemen persyaratan ini dan masukkan kasus nilai komoditas tidak melebihi Rp. 2.500.000,00. Oleh karena itu, perkara tersebut diperiksa dengan prosedur yang dipercepat, yang diadili oleh hakim, dan penugasan serta peninjauan kembali perkaranya dilakukan oleh penyidik sendiri tanpa campur tangan jaksa.

\section{Saran}

Berdasarkan simpulan tersebut di atas, dapat dikemukakan saran kepada para pihak terkait, pertama, bagi aparat penegak hukum diharapkan peraturan baru ini dapat memberikan rasa keadilan dalam menjalankan tugas dan wewenangnya masing-masing, khususnya hakim dalam mengadili tindak pidana ringan, agar tidak bertentangan dengan tujuan undang-undang itu sendiri. Yang terakhir ini bertujuan untuk memberikan rasa keadilan. Kedua, kepada masyarakat diharapkan dengan adanya undang-undang permanen ini dapat meningkatkan kepercayaan masyarakat terhadap aparat penegak hukum dan tidak menjadikan kelemahan hukum itu sendiri sebagai peluang untuk melakukan tindak pidana. Masyarakat harus berperan aktif dalam proses penegakan hukum karena tanpa peran dan dukungan masyarakat, tata kelola hukum Indonesia tidak dapat terlaksana dengan baik.

\section{DAFTAR PUSTAKA}

Ariyanti, V. (2019). Kebijakan Penegakan Hukum dalam Sistem Peradilan Pidana Indonesia. Jurnal Yuridis, $6(2), 33-54$

Hamzah, A. (2004). Hukum Acara Pidana. Jakarta: Sinar Grafika.

Harahap, Y. (2009). Pembahasan Permasalahan dan Penerapan KUHP. Jakarta: Sinar Grafika.

Kartanegara, S. (2002). Hukum Pidana. Balai Lektur Mahasiswa.

Muntoha. (2009). Demokrasi dan Negara Hukum. JURNAL HUKUM, 16(3), 379-395.

Niniek, S. (2007). Eksistensi Pidana Denda dalam Sistem Pidana dan Pemidanaan. Jakarta: Sinar Grafika.

Projodikoro, W. (2003). Tindak-Tindak Pidana Tertentu di Indonesia. Bandung: PT Refika Aditama.

Rompas, E. (2013). Pengawasan dalam Proses Penyidikan Tindak Pidana Menurut KUHAP. Lex Crimen, 1(2), 86-93.

Zaidan, M. A. (2014). Norma, Sanksi dan Teori Pidana Indonesia. Jurnal Yuridis, 1(1), 107-124.

Zulkifli, Fitriati, \& Ferdi. (2018). Penerapan Unsur Tindak Pidana Korupsi Pada Pelaksanaan Program Kemitraan dan Bina Lingkungan. Unes Law Review, 1(2). 